\title{
5
}

\section{China's interaction with the global economy}

\author{
Nicholas R. Lardy
}

A key element of Deng Xiaoping's economic reform strategy was to abandon the Maoist ideal of national self-sufficiency and start reaping the gains available from participating in global trade. The result has been an expansion of China's trade that has outpaced the growth of its domestic economy and far exceeded the growth of global trade for almost three decades. Since reforms were launched, imports and exports as a share of China's economy have expanded greatly and China's share of global trade has grown tenfold. In 2004, China surpassed Japan to become the world's third largest trading economy, a remarkable achievement given that China's economy is only two-fifths the size of Japan's. ${ }^{1}$ This chapter analyses two issues: China's bilateral trade with the United States and China's exchange-rate policy.

\section{The origins of China's trade surplus with the United States}

China's ever-growing bilateral trade surplus with the United States has, appropriately, received increasing attention in recent years as China's global trade and current account surpluses have increased. In 2005, after rising modestly for several years, China's global trade surplus tripled to more than US\$100 billion. Meanwhile, its current account surplus soared to US $\$ 161$ billion—more than 7 per cent of GDP—-making China, in dollar terms, the world's second largest surplus country, only slightly behind Japan. ${ }^{2}$ In the first half of 2006, China's trade surplus expanded by about 50 per cent and it was on track to become the world's largest current account surplus country.

China's bilateral surplus with the United States increased steadily in the 1990s and, by 2003 , China moved into the unenviable position of being the single largest 
source of the overall United States balance of trade deficit. By 2005, the United States bilateral deficit with China reached US $\$ 202$ billion, accounting for a record 26 per cent of the total United States global trade deficit of US\$782 billion. As a result, many, including some in the United States Congress, see China as having replaced Japan as the principal mercantilist trader in Asia and the major source of lost United States jobs, particularly in manufacturing.

The United States bilateral trade deficit with China presents a complex and multifaceted challenge. The analysis below takes up five potential explanations for the deficit: restrictive United States export licensing; suggestions that China restricts access to its domestic market and pursues a mercantilist trade strategy; China's low-wage advantage; China's role in Asian production networks; and the undervaluation of the Chinese currency. These five alternative explanations are not mutually exclusive; indeed, several of them might be in play at the same time.

\section{Restrictive United States export licensing}

Chinese government officials regularly assert that the bilateral trade imbalance would be substantially less if the United States approved more high-technology exports to China. Yet, because of the liberalisation of export controls over the years, very few products now require licences for export to China, so the value of potential exports for which licences are sought is quite small—and the Department of Commerce approves the majority of applications. In the 2005 fiscal year, for example, United States exporters applied for licences to export products to China valued at US $\$ 3$ billion. The department approved licences covering US $\$ 2.4$ billion, or 80 per cent of the total. It returned applications covering US\$590 million if, for example, they were incomplete, and denied licences covering US\$12.5 million in potential sales (Department of Commerce, forthcoming).

That means that if the Department of Commerce had approved all of the licences rejected in the 2005 fiscal year, United States exports to China would have increased by only US $\$ 12.5$ million and the bilateral trade deficit would have been a mere 0.006 per cent smaller. If it had approved the rejected and returned applications, the bilateral deficit would have been reduced by only 0.3 per cent. ${ }^{3}$ In sum, the frequent claim by Chinese officials that liberalising export licensing would significantly reduce the bilateral trade deficit does not seem plausible.

How open is the Chinese economy?

The most common reason given by China's critics for the large and growing United States-China trade imbalance is that China is pursuing a mercantilist trade strategy, systematically restricting access to its market while aggressively supporting exports 
by national firms. Certainly the flood of Chinese goods into the United States, particularly into the stores of mass merchandisers such as Wal-Mart, Target, Circuit City and Best Buy, suggests, to many observers, that China's high rate of economic growth is explained in large part by its recent export boom. But the appearance of huge volumes of Chinese goods in United States retail outlets is not sufficient to demonstrate that the Chinese economy is relatively closed to imports.

Several analytical approaches are required to examine this issue. First, of course, any evaluation of China's openness based on its trade position must be on the basis of its global trade balance or its global current account position, rather than its bilateral trade balance with the United States. There is no economic basis for preferring balanced bilateral trade; indeed, the presumption is the opposite.

For most of the reform period, China's global current account surplus has been relatively modest. For example, from 1993 to 2002, China's current account fluctuated between a deficit of 2 per cent and a surplus of 4 per cent of GDP, but the average position was a surplus of only 1.6 per cent. This was about half of Japan's average surplus of 2.9 per cent of GDP during the decade 1984-93, when its global surpluses loomed largest relative to the size of its economy. As already noted, however, China's current account position has risen sharply since 2002 and it now has become a major contributor to global economic imbalances.

Second, the Chinese government has materially reduced barriers to imports. For example, the average level of applied import tariffs dropped from more than 50 per cent in 1982 to less than 10 per cent in 2005. Compared with many developing countries, China's average import tariff rate is relatively low. China's applied import tariff rate in 2004 was 10.4 per cent, compared with rates in India, Mexico, Brazil and Indonesia of 29.1, 18, 12.4 and 6.9 per cent, respectively (Figure 5.1). Moreover, import tariff exemptions in China are so widespread that the effective tariff ratio-that is, import tariff revenue collected relative to the value of the imports-is much lower than the average applied tariff. For example, the total value of import tariffs collected as a share of the value of imports fell from about 15 per cent in the mid 1980s to only 2.2 per cent in 2004 (Figure 5.2). The effective tariff protection provided to domestic firms in China is among the lowest of any developing country. ${ }^{4}$

Similarly, the number of goods that the Chinese government has subjected to an import licensing requirement or a specific numerical limit, such as an import quota, has dropped precipitously. At the peak in the late 1980s, the government imposed a licensing requirement on almost half of all goods imported into China. By the eve of China's entry into the World Trade Organization (WTO) in 2000, the authorities had reduced this share to less than 4 per cent and, under the terms of China's 
Figure 5.1 Applied tariff rates, China and other emerging markets, 2004 (per cent)

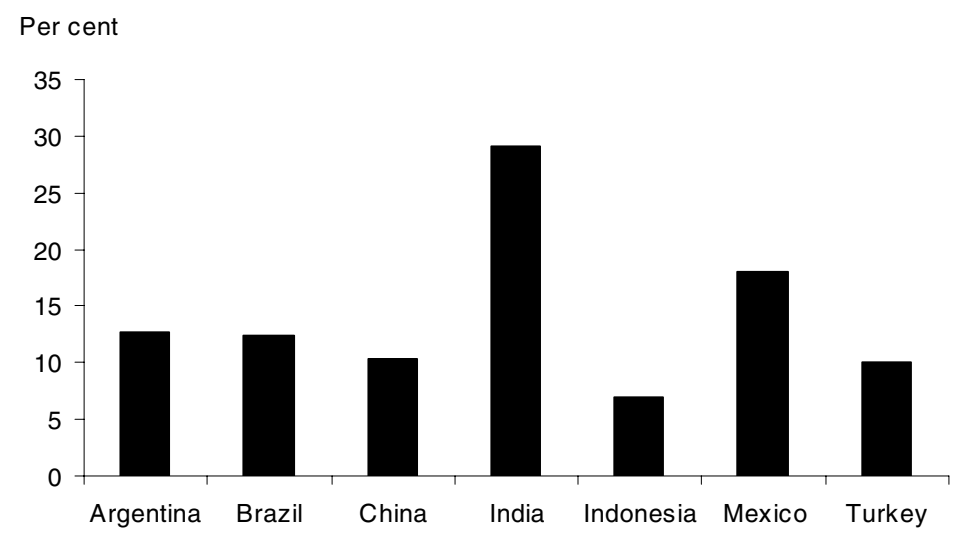

Source: World Trade Organization, 2005. Online Statistics, Trade Profiles. Available online at <stat.wto.org/CountryProfile/WSDBCountryPFHome.aspx? Language=E> (accessed 22 November 2005).

\section{Figure 5.2 China's import tariff revenue as a percentage of the value of} imports, 1978-2004

Sources: National Bureau of Statistics of China, 1982. China Statistical Yearbook 1981, Hong Kong Economic Information Agency, Beijing:353; National Bureau of Statistics of China, 1985. China Statistical Yearbook 1985, Statistical Publishing House, Beijing:494; National Bureau of Statistics of China, 2000. China Statistical Yearbook 2000, China Statistics Press, Beijing:258, 588; National Bureau of Statistics of China, 2005. China Statistical Yearbook 2005, China Statistics Press, Beijing:272, 626. 
accession to the WTO in 2001, the government eliminated all remaining licensing requirements in 2005. Similarly, the government eliminated all import quotas by 2005, except those that were part of a tariff rate quota arrangement. China agreed to such arrangements for a handful of agricultural products as part of the marketopening measures it made when it joined the WTO (Lardy 2002:75-9).

Third, the extent to which an economy is open can be measured by examining the ratio of imports to GDP. This ratio has soared in China, from 5 per cent in 1978 to 30 per cent in 2005 (Figure 5.3). Thirty per cent is roughly twice the ratio of imports to GDP in the United States and more than three times the ratio in Japan. It is also higher than other geographically large developing countries such as Argentina, Brazil and India. Indeed, only geographically small economies, such as Taiwan and South Korea, have import ratios as high, or higher than China.

Finally, throughout the 1990s, China was the fastest growing export market for United States firms-a trend that accelerated from 2000 to 2005, as exports of United States firms to China rose by 160 per cent while exports to the rest of the

\section{Figure 5.3 Imports as a percentage of GDP in China, 1978-2005}

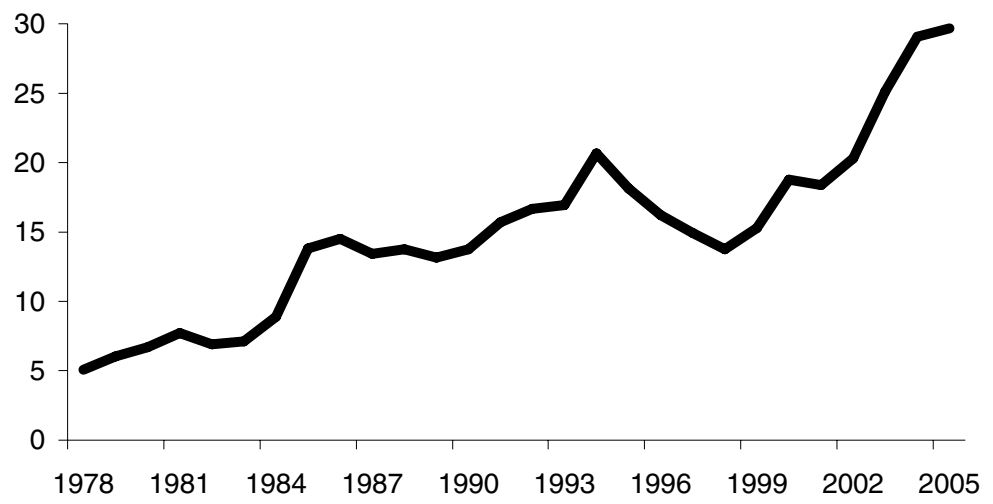

Sources: World Trade Organization, 2005. WTO Online Statistics, Time Series. Available online at <stat.wto.org/StatisticalProgram/WSDBStatProgramHome.aspx? Language=E> (accessed 28 November 2005); National Bureau of Statistics of China, 2005. China Statistical Yearbook 2005, China Statistics Press, Beijing:51; National Bureau of Statistics of China, 2006. Table of GDP at Current Prices. Available online at <www.stats.gov.cn/tjdt/zygg/ P020060109431083446682.doc> (accessed 9 January 2006); International Monetary Fund, 2002. IMF International Financial Statistics Yearbook 2002, International Monetary Fund, Washington:354-5; State Administration of Foreign Exchange of China, 2006. Table of Exchange Rates of RMB. Available online at <www.safe.gov.cn/0430/tjsj.jsp?c_t=3> (accessed 27 February 2006). 
world rose by only 10 per cent. Indeed, China alone accounted for one-quarter of the global export expansion of United States firms during that period.

In summary, it is difficult to sustain the charge that China's trade regime (as opposed to its exchange-rate policy, about which see below) reflects the traditional mercantilist approach of restricting imports. Except for very recent years, China's global current account surplus has been modest, its import tariffs are among the lowest of any developing country and the magnitude of its imports relative to the size of its economy is growing rapidly and is relatively high.

That is not to say that expanding trade has not been an important source of economic growth; it has been, but not because net exports, in an accounting sense, have been a major driver. Net exports have contributed positively to growth in only about half of the years between 1978 and 2005. Net exports fell—meaning that trade reduced economic growth-in almost as many years as they rose. Rather, trade's contribution to China's economic growth has been indirect, through its influence on China's domestic market structure. Increased openness to trade has greatly increased competition in the domestic market, which in turn has stimulated domestic firms to become more productive.

\section{China's low-wage advantage}

Some observers argue that a huge United States bilateral trade deficit with China is inevitable since it is impossible for United States firms to compete with firms with access to low-wage Chinese labour. There is no doubt that wages in China are very low compared with wages in the United States: the average monthly wage in manufacturing establishments in urban areas is only about US $\$ 120$ (Banister 2004); wages in manufacturing outside urban areas and for unskilled labour are even lower. Taking into account bonuses, incentive pay and fringe benefits, the total average hourly labour cost in manufacturing in urban areas in China is about US $\$ 1$, compared with almost US $\$ 30$ in the United States (Bureau of Labor Statistics 2005).

Focusing simply on the level of wages or even on total labour costs, however, is misleading. Wages in China are low primarily because productivity is low. The World Bank, for example, calculates that average value added per United States manufacturing worker in 1995-99 was 28 times the Chinese level (World Bank 2002:64-6). The average unskilled Chinese worker might earn about only onethirtieth the wage of his or her United States counterpart, but since the productivity of a Chinese worker on average is only a small fraction of that of an American worker, the Chinese firm will not be able to sell the good in question for onethirtieth of the United States firm's price. 
Moreover, wages are only one component of the overall cost of producing any good. Low wages are more likely to be a source of comparative advantage in industries where labour is a larger share of total costs-for example, shoes and apparel-than in industries such as semiconductor fabrication, in which wages are only 5 per cent of total production costs. Thus China's imports of semiconductors and microprocessors soared from US\$3 billion in 1995 to US\$90 billion in 2005, when China imported two-fifths of global production of these products. On the other hand, wages constitute about 20 per cent of the cost of producing apparel in the United States (Hufbauer and Yee Wong 2004:43). Firms operating in China clearly do have a comparative advantage in these products, as reflected in their high market share in countries that do not impose quotas or otherwise restrict apparel imports.

A comparison of wages in China with those in other developing countries also confirms that wages alone do not determine a nation's competitiveness. Countries in South Asia and in sub-Saharan Africa all have wages and total labour costs that are even lower than those prevailing in China, but few firms in these countries are large exporters to the United States. For many of these countries, the productivity gap vis-à-vis United States workers is even greater than for Chinese workers, reflecting low levels of educational attainment and other factors. In addition, many of these countries, unlike China, have failed to provide an attractive environment for foreign investors or to invest in the physical infrastructure necessary to support large volumes of international trade. India, for example, continues to impose many restrictions on inward foreign direct investment and is currently investing only one-seventh as much as China in infrastructure.

In short, the low wages of Chinese workers provide an advantage for Chinese firms in international trade, but not one that is insurmountable in many sectors where the United States maintains a comparative advantage. United States wages are among the highest in the world, but the United States remains the world's second largest exporter after Germany, another high-wage country. United States policy should be directed towards further enhancing the productivity advantage of United States workers, in order to maintain high wage rates in the United States, rather than trying to compete with Chinese exports of labour-intensive products.

\section{China's critical role in Asian production networks}

The single most persuasive explanation of the growing United States bilateral deficit is that it reflects the consolidation in China of the final assembly stage of Asian production networks. In the past two decades, the production process for a growing range of manufactured goods has become increasingly disaggregated on a geographic basis. Each country serves as the location for the portion of the 
production process in which it has the strongest comparative advantage. Higherincome, more technologically advanced countries have come to specialise in producing high value-added parts and components, while China, given its large pool of labour available for work in unskilled, labour-intensive operations, has increasingly become the location of choice for the final assembly of a broad range of goods, especially electronic and information technology products.

Joint ventures and wholly foreign-owned firms carry out a large portion of this assembly. Cumulative direct foreign investment in China by the end of 2005 was US $\$ 610$ billion, with almost two-thirds concentrated in the manufacturing sector. Most of this investment originates in other Asian economies and is in processing and assembly operations.

Goods that are assembled from imported parts and components now account for almost 60 per cent of China's total exports and about 65 per cent of the goods China exports to the United States. When these goods are exported from China to the United States, their entire value is counted by United States Customs as imports from China. In fact, on average, about two-thirds of the value of these socalled 'processed exports' originates outside China, mostly in other Asian countries. The key point is that the geographic disaggregation of the production process for an ever-growing volume of traded goods means that the significance of bilateral trade data is much diminished today compared with an earlier era, when most production was organised vertically rather than horizontally.

China's rise as the point of final assembly for a broad range of goods is reflected in the sharp decline in the past two decades in the share of the US bilateral trade imbalance that originates in Hong Kong, Taiwan, South Korea and Japan. As these countries have moved manufacturing capacity to China-and, in the case of Japanese cars, to the United States-the share of the United States trade deficit that they account for has fallen by three-quarters, from more than 50 per cent in 1985 to less than 14 per cent in 2005, while China's share has risen from nothing to one-quarter (Figure 5.4). Between 1985 and 2005, the United States global trade deficit as a share of GDP more than doubled, reflecting a further deterioration of the United States savings-investment balance. But the share of this deficit accounted for by the combination of China, Hong Kong, Taiwan, South Korea and Japan declined by one-quarter.

\section{Undervaluation of the Chinese currency}

The fifth potential explanation for the growing United States bilateral trade imbalance with China is the undervaluation of the Chinese currency, the renminbi. It is important to note that China has had a growing trade surplus with the United 
Figure 5.4 Share of US trade deficit by region, 1985 and 2005 (per cent)
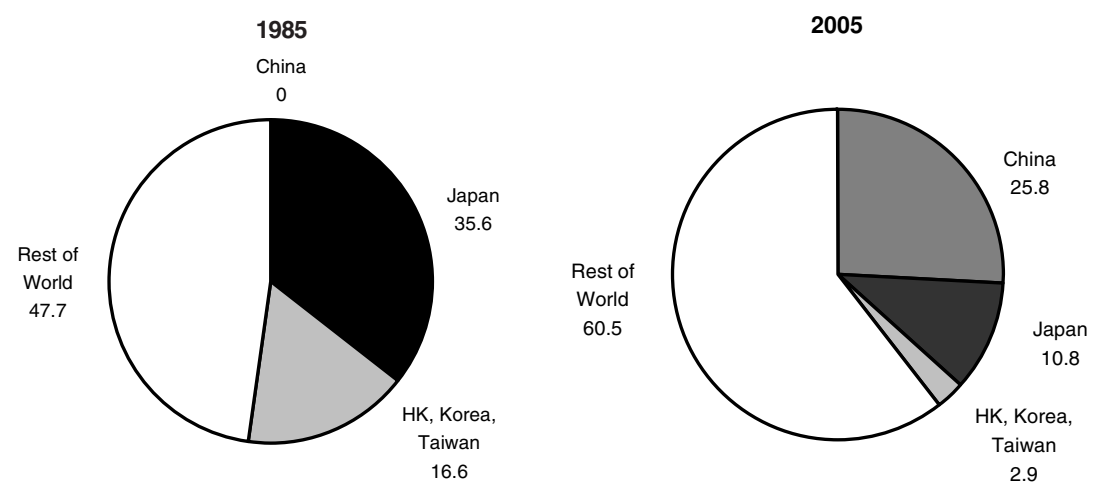

Source: US Department of Commerce, 2006. US International Transactions Accounts Data, Table 2. US Trade in Goods, Bureau of Economic Analysis, International Economic Accounts. Available online at $<w w w . b e a . g o v /$ bea/international/bp_web/ simple.cfm?anon=71\&table_id=2\&area_id=3> (accessed 30 June 2006).

States since the mid 1980s, but at least until 1994, by almost every available measurement, the renminbi was substantially overvalued rather than undervalued. Nonetheless, there can be little doubt that the increasing undervaluation of the Chinese currency since 2002 has exacerbated the underlying structural imbalance in bilateral trade - that is, China's emergence as the main point of final assembly in Asian production networks.

This means that even if the United States global trade deficit shrinks, the United States is likely to continue to have a large bilateral deficit in its trade with China. ${ }^{5}$ After all, the bilateral deficit grew steadily as Asian manufacturers relocated to China starting in the second half of the 1980s, even as the United States global trade deficit fell from its peak of US $\$ 160$ billion or 3.4 per cent of GDP in 1987 to a low of US $\$ 77$ billion or 1.3 per cent of GDP in 1991. Consequently, a policy focusing on achieving a sustained reduction in the bilateral trade deficit with China will almost certainly fail. The US government should focus instead on policies that reduce China's global current account surplus. 


\section{China's currency regime}

Given China's fixed peg to the US dollar, the renminbi depreciated on a real tradeweighted basis after February 2002, when the value of the dollar began to depreciate significantly vis-à-vis major floating currencies such as the euro, the Canadian and Australian dollars and the British pound. As a result, China's current account surplus, which had averaged only 1.6 per cent of GDP in the decade to 2002, rose moderately to 3 per cent of GDP in 2003 and to 3.6 per cent in 2004. The underlying global surplus in those years, however, was undoubtedly somewhat higher than the actual one. Since economic growth was extremely rapid, demand for imported raw materials and capital goods was growing at an above-average rate, meaning that China's global trade and current account surpluses were smaller than they otherwise would have been. In addition, starting in 2002 the full effects of the depreciation of the renminbi would raise exports and constrain imports, were not yet reflected fully in the trade balance. In 2005, as domestic demand in China softened somewhat and the effects of the renminbi's real depreciation were reflected more fully in the trade account, China's trade surplus tripled to just more than US $\$ 100$ billion and the current account reached US $\$ 161$ billion-7.2 per cent of GDP. 6

In July 2005, Chinese authorities launched a reform of the exchange-rate regime that had several components: revaluing the renminbi by 2.1 per cent against the US dollar; announcing that the currency could fluctuate by up to 0.3 per cent a day and that its value would be determined increasingly by supply and demand in the market; and asserting that the renminbi would be managed against a basket of currencies rather than being pegged simply to the dollar. Since that time, the central bank has introduced a number of technical reforms that provide a more suitable market infrastructure for a flexible exchange regime.

At least through the first half of 2006, however, these reforms did little to alleviate China's large and growing external imbalance. In part, this is because the initial currency revaluation of 2.1 per cent was far too small. With fellow economist Morris Goldstein, I estimated in 2003 that the extent of undervaluation on a real trade-weighted basis was in the range of 15-25 per cent (Goldstein and Lardy 2003). By the summer of 2005 , the undervaluation was more likely in the range of 20-40 per cent (Goldstein 2005).

In addition, the potential for the currency's value to move by as much as 0.3 per cent a day was theoretical—massive intervention continued to prevent the currency from appreciating. In the five months from July to December 2005, the authorities purchased an average of US $\$ 19$ billion a month in foreign exchange, almost exactly 
the pace of intervention that occurred in the first six months of the year. As a result, the cumulative additional appreciation of the renminbi against the dollar was only 0.8 per cent. Finally, there is little evidence of pegging to a basket of currencies. China's exchange-rate system remains a heavily managed peg to the dollar, and at a little changed dollar rate (Goldstein and Lardy 2006:13).

China's large external imbalance poses a major risk to the global economyand so does that of the United States. As a result of its large and growing current account deficits of recent years, the United States' international financial position has been transformed. Whereas until the mid 1980s the United States was a net creditor country, it has become a large net debtor. These debts now exceed onequarter of US GDP, and, if the current account imbalances of recent years are not reduced to a more manageable level, US net debt to the rest of the world will continue to rise. Most observers believe this path is not sustainable because the foreign appetite for holding dollar-denominated assets will eventually be satiated. In addition, these large and growing US external deficits are a major cause of trade protectionism in the Congress and elsewhere in the United States.

Ultimately, the adjustment of the current large external imbalances must involve a depreciation of the US dollar, an improvement in the US national savingsinvestment balance, requiring that domestic demand grow more slowly than domestic output, thus making room for expanding US net exports, and a more rapid growth of domestic demand than domestic output in the rest of the world, thus leading to expanding net imports, the counterpart of expanding US net exports (Mussa 2005:175-207).

China has a key role in this process. As the world's second largest surplus country, China must allow its currency to appreciate against the dollar and it must take steps to allow a transition to a growth path driven more by domestic consumption than by further increases in its external surplus.

China is the prime candidate to lead in allowing its currency to appreciate, for several reasons. It has a huge and rising external surplus, reflecting the substantial undervaluation of its currency. In addition, the dollar has already depreciated substantially against the world's major floating currencies, but needs to depreciate by an additional 25-30 per cent in order to reduce global imbalances to a sustainable level. A substantial portion of this additional adjustment must come from Asia, where in recent years several countries, in addition to China, have intervened in the markets to prevent their currencies appreciating - thus limiting the overall depreciation of the dollar. At least in some Asian countries, appreciation has been avoided because of a concern about a loss of national competitive position to 
China in third-country markets. Thus, if China were to allow its currency to appreciate significantly it likely would lead to the desired general appreciation of Asian currencies against the dollar. ${ }^{7}$

Moreover, if China were to continue to intervene in the market, thus allowing its currency to appreciate only at the glacial pace evident since the summer of 2005, it would increase the risk of stimulating a protectionist response in the United States and perhaps elsewhere.

\section{Acknowledgment}

This chapter is adapted from Chapter 4 of Bergsten et al. 2006.

\section{Notes}

1 As measured by the sum of imports and exports China became the world's third largest importer in 2003.

2 Japan's current account surplus in 2005 was US\$164 billion.

3 These calculations ignore the fact that the licensing data are for the 12 months ending September 2005, while the trade data are for calendar year 2005.

4 When the ratio of import duties to the value of imports in China averaged 2.7 per cent in 199698, the ratios for Argentina, Brazil, India, Indonesia, Mexico and Turkey, respectively (for slightly varying multiple-year periods from 1996 to 2002), were 7.8, 8.4, 18.2, 1.2, 1.9 and 1.8 per cent. World Trade Organization, 2006. Country Profiles. Available online at <http:// stat.wto.org?CountryProfiles.htm> (accessed 25 January 2006).

5 Obviously, a major US recession that massively reduced imports across the board would constitute an exception to this forecast.

6 GDP growth in 2005 moderated only slightly to 9.9 per cent compared with 10.1 per cent in 2004 . However, since the contribution of net exports to growth in 2005 was at an all-time high, in the neighbourhood of one-quarter, domestic investment and/or consumption demand must have slowed significantly.

7 It should be noted that if other Asian countries were to allow their currencies to appreciate, the overall trade-weighted appreciation of the renminbi would be substantially less than its nominal appreciation against the dollar. 